\title{
Assessment of Smartphone Addiction among adolescents in a University
}

Rashmi Kundapur ${ }^{1}$, Harshitha Hanglur Narasimha' ${ }^{2}$, Sharon Baisil ${ }^{3}$, Sanjeev Badiger ${ }^{4}$

${ }^{1}$ Professor, Department of Community Medicine, K S Hegde Medical Academy, Nitte (Deemed to be University), Deralakatte, Mangalore; ${ }^{2}$ Postgraduate, Department of Community Medicine, K S Hegde Medical Academy, Nitte (Deemed to be University), Deralakatte, Mangalore; ${ }^{3}$ Senior Resident, Department of Community Medicine, MOSC Medical College, Kolenchery; ${ }^{4}$ Professor, Department of Community Medicine, K S Hegde Medical Academy, Nitte (Deemed to be University), Deralakatte, Mangalore

\begin{tabular}{|c|c|c|c|c|c|c|c|c|}
\hline Abstract & Introduction & Methodology & Results & Conclusion & References & Citation & \multicolumn{2}{|c|}{ Tables / Figures } \\
\hline \multicolumn{9}{|c|}{ Corresponding Author } \\
\hline \multicolumn{8}{|c|}{$\begin{array}{l}\text { Dr. Harshitha H N, Postgraduate, Department of Community Medicine, K S Hegde Medical Academy, Nitte } \\
\text { (Deemed to be University), Deralakatte, Mangalore } \\
\text { E Mail ID: harshi.hn@gmail.com }\end{array}$} & 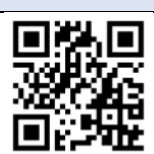 \\
\hline
\end{tabular}

\section{Citation}

Kundapur R, Harshitha H N, Baisil S, Badiger S. Assessment of Smartphone Addiction among adolescents in a University. Indian J Comm Health. 2020;32(1):161-163.

Source of Funding: Nil Conflict of Interest: None declared

\section{Article Cycle}

Received: 01/07/2019; Revision: 20/01/2020; Accepted: 15/02/2020; Published: 31/03/2020

This work is licensed under a Creative Commons Attribution 4.0 International License.

\section{Abstract}

Introduction: A smartphone is a combination of cellphone and handheld computers that created the greatest tech revolution since the Internet. The official name for smartphone addiction is Nomophobia which is defined as having a fear of not being with your phone. Objective: To assess the smartphone addiction among adolescents and its association with socio demographic factors. Methodology: A cross sectional study among adolescents in a university in Mangalore among students $<19 y$ rs of age. Sample size was estimated using the prevalence formula, taking prevalence as $50 \%$ and allowable error of $5 \%$. A validated, self-administered questionnaire was used for assessment. Proportion for addiction and Chi Square analysis was done. Results: A total of 426 students were enrolled for the study. The prevalence of smartphone addiction was $57 \%$ in the study population, females had higher addiction scores than males. There was significant association of family annual income, monthly pocket money and occupation of the father with smartphone addiction. Conclusion: The prevalence of smartphone addiction among adolescents is high. The results of our study showed that smartphone addiction is more prevalent in the families with higher economic status.

\section{Keywords}

Adolescent; Smartphone; Cross-Sectional Studies; Computers, Handheld; Cell Phone; Surveys and Questionnaires

\section{Introduction}

A smartphone is a combination of cellphone and handheld computers. It combines a cellphone with email and Web, music and movie player, camera, camcorder, GPS navigation, voice recorder, alarm clock, flashlight, photo album, address book and a lot more. (1)

Addiction is a complex condition, a brain disease that is manifested by compulsive substance use despite harmful consequence. (2) The official name for smartphone addiction is Nomophobia which is defined as having a fear of not being with your phone. A survey showed that teenagers who spend $5 \mathrm{hrs}$ a day on electronic devices are $71 \%$ more likely to have suicide risk factors than those with 1 hour of use. (3)

\section{Aims \& Objectives}

To assess the addiction of smartphone among adolescents and its association of smartphone addiction with sociodemographic factors.

\section{Material \& Methods}

A cross sectional study was conducted in the colleges belonging to a single university in Mangalore over 6 months period. The sample size was estimated using the prevalence formula. Considering the prevalence of smartphone addiction among adolescents as $50 \%$, the allowable error of $5 \%$ the final estimated sample size was 400. All the students who were less than 19 years of age were enrolled into the study. Ethical clearance was obtained from the Institutional Ethics Committee. 
Participants were provided with information about the study and written informed consent was taken from the participants. A self-administered questionnaire was given to whoever present on that day of class. Absentees of the class on the day of data collection were not considered for the study. Face validation of the questionnaire was done before the start of the study. Students were given 30 minutes for filling of the questionnaire. Each answer was scored. If the score was above 31 it was considered as addiction. Family income was divided into categories, i.e. $<3,00,000$ and $>3,00,000$ rupees per annum. The pocket money of the students was categorized as < $<00,500$ 2500, 2500-5000 and more than 5000 rupees per month. Data was cleaned and entered into Microsoft Excel for analysis. Data was analyzed using SPSS 16 Proportion of calculated addiction score and Chi square test for demographic data was done. $P$ value $<0.05$ was considered significant. Clearance was obtained from the Institutional Ethics Committee before the start of the study.

\section{Results}

A total of 426 students were enrolled for the study. $53.6 \%$ of the study population were females. Out of $426,57 \%$ of the students i.e. 246 adolescents were found to have addiction towards smartphone. Addiction was more among females than among males in our study. (Table.1) On enquiring about students experiencing health related issues due to smartphone usage, 50\% agreed that they have experienced such difficulty. $57 \%$ of the students agreed that they are unable to complete assignments and work to their full potential in the class due to the usage of smartphones. $59 \%$ of the students agreed that they have signs of smartphone addiction.

Smartphone addiction was assessed for association with occupation of the father, family income and the pocket money students receive per month. There was significant association between occupation of the father and smartphone addiction. Students whose father were working as semi-professional i.e., including businessmen were found to have high risk for addiction. There was also a significant association between family income and smartphone addiction. Student's family who earned more than 3,00,000 rupees had higher chances of addiction to smartphone. Smartphone addiction was also found to be significantly associated with pocket money student receives per month. (Table 1),(Table 2),(Table 3 )\&(Table 4)

\section{Discussion}

The prevalence of smartphone addiction according to our study was $57.9 \%$ among the adolescents. A study done in Maharashtra to assess the mobile phone dependence among undergraduate students showed that $82 \%$ of the students were dependents. More number of females were found to be dependent than males. (6) A study done in Vadodara among the students for smartphone addiction showed that $31.5 \%$ of them were moderately addicted. (7) A cross sectional study done in China among undergraduates of medical college showed that prevalence of smartphone addiction was $29.8 \%$. Females were mostly using it for multimedia applications while males reported using of gaming applications. (8) Similar findings were observed in our study results that females had more addiction than male students. This finding may be attributed to the higher usage of the social media by the female students. Males report the usage of cellphone for the gaming purpose which is often replaced by computers. A study done in Switzerland showed that addiction to smartphone was found among $16.6 \%$ of the adolescents. Younger adolescents $<15$ yrs. had higher prevalence of addiction than older adolescents. (9)

A study done in Germany among adolescents showed that girls are more prone to become addicted to smartphones than boys, similar findings were seen in our study also where $63 \%$ of the females were found to have addiction scores higher than cutoff. (10)

A study done in Saudi Arabia showed that $27 \%$ of the students were spending more than $8 \mathrm{hrs}$. using their smartphones which was affecting their academic achievement and lifestyle.(11) A study done in Lebanon to ascertain whether depression or anxiety, independently, contributes to smartphone addiction level showed that depression and anxiety were independent positive predictor of smartphone addiction. (12) Usage of smartphone was found to have health related issues and academic issues among students in our study too. Students reported of physical and psychological symptoms.

There is need to monitor the usage of smartphone among the students of university as most of them stay in hostels during the professional course studies. If the addiction goes unchecked it can result in several adverse effect on health and influence the academic performance of the students.

\section{Conclusion}

Smartphone addiction among adolescents is of grave concern as it can directly affect physical and psychological health. The results of our study showed that smartphone addiction is more prevalent in the families with higher economic status.

\section{Recommendation}

The smartphone uses among adolescents need to be monitored for the prevention of undue adverse effects. Institutions should restrict the usage during the college hours and monitor the usage in the hostel.

\section{Limitation of the study}

The limitations of the study include that the study was conducted in a single university which could have bias. Sample selection was not done based on probability proportional to size. 


\section{Relevance of the study}

The study shows the presence of smartphone addiction in more than $50 \%$ of the participants. There is a need for screening of adolescents and adequate intervention to be planned for prevention of addiction affecting mental health of students.

\section{Authors Contribution}

RK, SB, SBA: Conception of design, analysis and interpretation, revising the article and final approval. $\mathrm{HNH}$ : Conception of design, data collection, analysis and interpretation, revising the article and final approval.

\section{References}

1. Smartphone Definition from PC Magazine Encyclopedia [Internet]. Pcmag.com. 2019 [cited 29 March 2019]. Available from https://www.pcmag.com/encyclopedia/term/51537/smartphone

2. What Is Addiction? [Internet]. Psychiatry.org. 2019 [cited 29 March2019]. Available from: https://www.psychiatry.org/patientsfamilies/addiction/what-isaddiction

3. Smartphone Addiction \& Cell Phone Usage Statistics in 2018 [Internet]. BankMyCell. 2019 [cited 29 March 2019]. Availablefrom: https://www.bankmycell.com/blog/smartphoneaddiction/\#chapter1

4. Manimegalai $V$ et al., A study on Impact of Mobile phone Addiction on Adolescent's Life in Erode District Inter. J. Int. Adv. \& Res. In Engg. Comp., Vol.-06(02) 2018 [861-864]
Assessment of Smartphone Addiction in Indian Adolescents: A Mixed Method Study by Systematic-review and Meta-analysis Approach. (2014). International Journal of Preventive Medicine, 5(12), pp.1500-1511.

6. Domple VK, Wadde SK, Gattani P L. Mobile phone dependence among undergraduate medical students in Nanded city. Ann Trop Med Public Health [serial online] 2017 [cited 2018 Oct 24];10:27$30 . \quad$ Available from: http://www.atmph.org/text.asp?2017/10/1/27/205537

7. Patel A, Patel A, Patel D, Patel D, Patel D, Patel J et al. Assessment of Smartphone Addiction among Undergraduate Students of Sumandeep Vidyapeeth, Vadodara. International Journal of Nursing Education and Research. 2017;5(1):16.

8. Chen B, Liu F, Ding S, Ying X, Wang L, Wen Y. Gender differences in factors associated with smartphone addiction: a cross-sectional study among medical college students. BMC Psychiatry. 2017;17(1).

9. Haug, S., Castro, R., Kwon, M., Filler, A., Kowatsch, T. and Schaub, M. (2015). Smartphone use and smartphone addiction among young people in Switzerland. Journal of Behavioral Addictions, 4(4), pp.299-307.

10. Randler C, Wolfgang L, Matt K, Demirhan E, Horzum M, Beşoluk Ş. Smartphone addiction proneness in relation to sleep and morningness-eveningness in German adolescents. Journal of Behavioral Addictions. 2016;5(3):465-473

11. Alosaimi F, Alyahya $H$, Alshahwan H, Al Mahyijari N, Shaik S. Smartphone addiction among university students in Riyadh, Saudi Arabia. Saudi Medical Journal. 2016;37(6):675-683.

12. MatarBoumoslehJ, JaaloukD (2017) Depression, anxiety, and smartphone addictionin university students- A cross sectional study. PLoS ONE 12(8):e0182239.https://doi.org/10.1371/ journal.pone.0182239

\section{Tables}

\begin{tabular}{|c|c|c|c|}
\hline & Male & Female & Total \\
\hline Addiction & 101 (51.01\%) & 145 (63.5\%) & 246 \\
\hline No Addiction & 97 (48.9\%) & $83(36.4 \%)$ & 180 \\
\hline Total & 198 & 228 & 426 \\
\hline
\end{tabular}

TABLE 2 ASSOCIATION OF SMARTPHONE ADDICTION AND FATHER OCCUPATION

\begin{tabular}{|c|c|c|c|c|}
\hline \multicolumn{4}{|c|}{ Classification } & \multirow[t]{3}{*}{ P value } \\
\hline & & No Addiction & Addiction & \\
\hline \multirow{4}{*}{$\begin{array}{l}\text { Occupation of } \\
\text { Father }\end{array}$} & Professional & $69(39.2 \%)$ & $76(31.8 \%)$ & \\
\hline & Semi-Professional & $52(29.5 \%)$ & $92(38.5 \%)$ & \multirow{4}{*}{$0.013^{*}$} \\
\hline & Skilled & $19(10.18 \%)$ & $41(17.2 \%)$ & \\
\hline & Clerical & 36 (20.5\%) & $30(12.6 \%)$ & \\
\hline \multicolumn{2}{|r|}{ Total } & 176 & 239 & \\
\hline
\end{tabular}

TABLE 3 ASSOCIATION OF POCKET MONEY STUDENT RECEIVES AND SMARTPHONE ADDICTION

\begin{tabular}{|c|c|c|c|c|}
\hline \multicolumn{4}{|c|}{ Classification } & \multirow[t]{2}{*}{ P value } \\
\hline \multicolumn{3}{|c|}{ No Addiction } & Addiction & \\
\hline \multirow{4}{*}{$\begin{array}{l}\text { Pocket Money } \\
\text { Per Month in } \\
\text { Rupees }\end{array}$} & $<500$ & $13(8.3 \%)$ & $31(13.0 \%)$ & \multirow[t]{5}{*}{$0.026^{*}$} \\
\hline & $500-2500$ & $86(54.8 \%)$ & $101(42.4 \%)$ & \\
\hline & $2500-5000$ & $44(28 \%)$ & $66(27.7 \%)$ & \\
\hline & $>5000$ & $14(8.9 \%)$ & $40(16.8 \%)$ & \\
\hline \multicolumn{2}{|l|}{ Total } & 157 & 238 & \\
\hline
\end{tabular}

TABLE 4 ASSOCIATION OF FAMILY INCOME AND MARTPHONE ADDICTION

\begin{tabular}{|c|c|c|c|c|}
\hline & & No Addiction & Addiction & P value \\
\hline \multirow[t]{2}{*}{ Family Income } & $<3,00,000$ & 47 (26\%) & $83(33.8 \%)$ & \multirow[t]{3}{*}{$0.019 *$} \\
\hline & $>3,00,000$ & $132(74 \%)$ & $162(66.2 \%)$ & \\
\hline \multicolumn{2}{|l|}{ Total } & 179 & 245 & \\
\hline
\end{tabular}

